\title{
長崎県における国際観光の動向と展望
}

\section{International Tourism in Nagasaki Prefecture, Japan}

\author{
北田 晃司 ${ }^{1}$ \\ Koji KITADA ${ }^{1}$
}

\begin{abstract}
要旨
近年，わが国では国際観光が着実な成長を続けている地域と，停滞傾向にある地域の差が拡大している。本研究に扮いては，特 に2000 年代以降停滞傾向が続いている長崎県を例に, その背景の分析および停滞状況からの脱却に向けての展望を行った。

長崎県は 400 年以上にわたり外国と交易を行ってきた伝統があり，海外との交流の中で形成された独自の文化を持っている。し かし日本を訪問する外国人観光客の多くは大都市でのショッピング，冬の雪景色，あるいは日本独自の文化的伝統などを高く評価 する傾向があり，そのことがこれらの観光資源に恵まれない同県の国際観光の停滞に大きな影響を及ぼしていることが明らかになっ た。また長崎県の観光地は団体観光客への依存率がかなり高いこと, 外国人観光客の間での知名度が日本人観光客に比べてはるか に低い観光地が多いことも，同県の国際観光の停滞の大きな要因であると考えられる。

このような状況にある長崎県の国際観光を立て直すためには，外国人観光客が観光地としての長崎県をより高く評価できる観光 のあり方を提示することと, 同県の観光地のもつ魅力を外国人観光客により積極的にアピールし，かつそれをより高く評価する可 能性のある外国人観光客の属性を正確に評価することが重要と考えられる。前者については, 2006 年に長崎市が開始した, 様々な 観光ルートを徒歩でめぐる「さるく」ルートを県内の他に市町村にも広げた上でより多くの外国人観光客に体験してもらうこと， 後者については，ちゃんぽんに象徵される中国文化の影響や，ローマ法王からも称賛を受けている隠れキリシタンの伝統，さらに はこれらの様々な文化的伝統が同じ場所に共存し，かつ新たな文化を生み出しているという事実を外国人観光客に積極的に伝えて いくことが挙げられる。そして今後は，時間や空間の多様性の確認を自らのアイデンティティとする地理学が国際観光により積極 的に参入していくことが望まれる。
\end{abstract}

キーワード：日本，国際観光，長崎県，外国人観光客

Key Words : Japan, international tourism, Nagasaki City, foreign tourists

\section{I . はじめに}

わが国の国際観光を長期的に見た場合，少なくとも 外国人観光客の訪問数については着実に増加してき た ${ }^{1)}$ 。このことを反映して，地理学においても近年， 国際観光を扱った研究が増加している。これらは主 に海外における国際観光を取り上げたもの ${ }^{2)}$ と，わ が国の観光地における外国人観光客の動向を扱った もの ${ }^{3)}$ に大別される。このうち後者の研究の多くは, わが国を訪問する外国人観光客の中で圧倒的割合を占 める ${ }^{4)}$, 東アジアの国または地域からの観光客の動向 に注目したものが多数を占めている。

しかしこれらの研究において多く使用されている， 外国人観光客に関する統計については, 調査項目が国 内観光客に比べて少ない, 都道府県ごとの調査項目の 差が大きい，あるいは調査が開始された年代が比較的 新しいなどといった問題を抱えており，特に長期間に
わたる時系列的研究を行うことが極めて困難な状況に ある。またこれらの研究の多くは, 前述のように東ア ジアからの外国人観光客の動向に注目したものが多数 を占めているが，それ以外の地域からの外国人観光客 については, まだ十分に検討されているとは言えない。

しかし日本の国際観光に注目した場合，実際には地 方によって外国人観光客の国籍構成に大きな相違が見 られることは無視できない。例えば近年，わが国にお いて外国人観光客の増加率が特に高い地域の 1 つであ

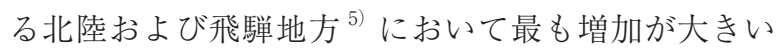
のは台湾, さらにはヨーロッパからの観光客であり (北 田，2012），逆に韓国や中国からの観光客はまだ少数 に留まっている。

また，各都道府県における外国人観光客の訪問率に ついても，東京都や京都府のように，国際的に知名度 の高い観光地を抱え, 近年も外国人観光客が増加して

1 近畿大学 · 非常勤講師 / Part-time lecturer, Kinki University, Japan 
いる都道府県がある一方で, 逆にわが国の国際観光に おける地位を低下させつつある県も存在し, 両者の間 には極めて対照的な状況が見られる。特に後者につい ては，その大半が東京，大阪などの大都市から遠い地 方, 特に西日本に位置している ${ }^{6)}$ 。中でも九州地方で は東アジアの国や地域から距離的に近く，また後述す るように 1990 年代まではわが国の国際観光において 重要な地位を占めていたにも関わらず, 近年, 外国人 観光客の訪問率が低下する傾向が見られる ${ }^{7)}$ 。

これらの状況から考えると, 今後, わが国の国際観 光, 特に外国人観光客の動向に注目して分析を進める 上では，各都道府県または地方における国際観光が日 本の国際観光においていかなる位置づけにあるのかよ り明確にすること，また東アジアのみならず，他の国 や地域からの外国人観光客の嗜好や観光行動も検討対 象とすること, さらに外国人観光客の嗜好や観光行動 と各地方や都道府県の観光資源との関係についても綿 密な分析を行うことなどが重要になると考えられる。

以上のことから本研究においては，かつてわが国の 国際観光において重要な役割を果たしていたものの, 現在, その地位を低下させつつある県の一例として長 崎県に注目し, 同県を訪問する外国人観光客の嗜好や 観光行動の検討を通して, わが国の国際観光における 同県の位置づけや国際観光の停滞要因, さらに今後な すべき対応について検討することにする。

\section{I . 長崎県における外国人宿泊客の時系列的分析}

本章においては長崎県 ${ }^{8)}$ を訪問する外国人観光客 のうち, 特に同県への宿泊客数の多い国籍の観光客に ついて, 訪問数の増減やその背景について分析を行う。

表 1 は 1990 年代および 2000 年代における, わが国 の国際観光における長崎県の位置づけの変化を示した

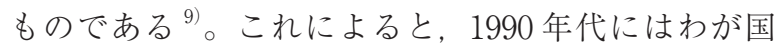
を訪問する外国人観光客数はまだ 2013 年の半分にも 及ばなかったものの ${ }^{10)}$, 当時の長崎県は訪日外客訪 問率については最高で全国第 8 位であり，特に 1997 年には全外国人の $10 \%$ 近くが同県を訪問したことが わかる ${ }^{11)}$ 。

しかし 2000 年代に入ると，たしかに外国人の宿泊 客実数（以下，宿泊客数と略記する）は 1990 年代よ りも増加しているものの，訪日外客訪問率は 5 〜 $6 \%$ 程度に過ぎず，また全国順位でも15 位前後と低迷し ている。このことからわが国の国際観光における長崎 県の地位は, 特に 2000 年代以降, 低下する傾向にあ ると言える。

また表 2 は長崎県全体および, 長崎市とその周辺, 佐世保市とその周辺, 島原半島, 対馬といった県内の 主要地区 ${ }^{12)}$ における外国人宿泊客数の推移を示した ものである。これによると同県においては長崎市とそ の周辺，佐世保市とその周辺の 2 地区における外国人 の宿泊客数が他の地区に比べてかなり多いことがわか る。しかし長崎市とその周辺における外国人宿泊客数 は比較的順調に増加しているのに対し, ハウステンボ
スを抱える佐世保市とその周辺における外国人宿泊客 数は増減の幅が大きく, 特に同地区における宿泊客数 が長崎県全体の外国人宿泊客数の増減を大きく左右し ていることがわかる。

続いて外国人観光客の国籍ごとの動向について検討 する。表 3 は長崎県における韓国人宿泊客数, 全国に おける韓国人観光客数および前者の後者に占める割合 を示したものである。韓国人宿泊客は 2002 年以降, 国籍別では最も多く，例えば 2007 年には 236,670 人 と全外国人宿泊客数（表 2) の 6 割近くを占めている。 また長崎県における韓国人宿泊客も特に 2000 年代以 降，全国における韓国人観光客の 1 割前後に達してお り，表 1 に示した全訪日外客の長崎県訪問率に比べて その割合ははるかに高い。

次に地区別に見ると，近年，特に韓国から地理的に 近く, 1999 年に同国の釜山との間に定期船が就航を 開始した対馬における宿泊客数の増加が大きいことが わかる。

なお長崎県における韓国人宿泊客数が最も多かった のは 2007 年である。その最も大きな要因としては, 2005 年にわが国で愛知万博が開催されたことを契機 に韓国からの短期観光客の訪日ビザが免除された ${ }^{13)}$ こと, さらには当時の円安ウォン高状況などが挙げら れる（読売新聞，2008 年 6 月 27 日）。しかし同年の 下半期以降, 同国の通貨ウォンの価值が大きく低下す るようになり ${ }^{14)}$, これ以降, 宿泊客数が 2007 年を上 回った年は存在しない。

また表 4 は韓国および台湾の団体ツアーによる九州 北部の主要観光地の訪問率を示したものである。これ によるとたしかに韓国人団体観光客は, 長崎県におけ る外国人宿泊客の過半数を占めているものの, 九州に おいて韓国人観光客に人気のある観光地の多くは長崎 県以外の県に分布しており, 韓国における, 長崎県の 観光目的地としての評価は必ずしも高いとは言えない。

表 5 は長崎県における台湾人宿泊客数, 全国におけ る台湾人観光客数および前者の後者に対する割合を示 したものである。2013 年現在, 長崎県における台湾 人の宿泊客数は韓国に次いで 2 番目に多く, 特にハウ ステンボスのある佐世保市とその周辺における台湾人 宿泊客数は例年, 県内における同宿泊客数の 7 割以上 を占めている。また前述のように長崎県の観光地に対 する評価も韓国人観光客より高い。

しかし 2000 年代に入ると宿泊客数は大幅に減少し ている。これは主に2000 年代以降, 台湾人観光客の 間で，北海道の人気が急上昇した影響が大きいと考え られ，しかもその影響は長崎県のみならず他の九州諸 県にも及んでいる ${ }^{15)}$ 。また台湾人の長崎県宿泊客数 が日本を訪問した全台湾人に占める割合も近年は $5 \%$ 前後に留まっている。このことは各国を訪問する外国 人観光客の増減に, 経済的要因や政治的要因と同様 に，あるいはそれ以上に外国人観光客の嗜好の変化が 大きな影響を与えることもあることを示していると言 える。 
表 1 わが国の国際観光における長崎県の位置づけの変化

\begin{tabular}{|c|c|c|c|c|c|c|}
\hline & 1994 年 & 1997 年 & 2002 年 & 2007 年 & 2010 年 & 2013 年 \\
\hline (1)長崎県に扔ける外国人宿泊客数（万人） & 6.5 & 21.5 & 19.7 & 39.8 & 31.9 & 38.1 \\
\hline (2)全国における外国人観光客数（万人） & 191.5 & 239.1 & 309.5 & 595.4 & 636.2 & 796.3 \\
\hline (3) (1) $\div$ (2) $(\%)$ & 3.4 & 9.0 & 6.4 & 6.7 & 5 & 4.8 \\
\hline (4)長崎県の訪日外客訪問率（\%) および全国順位 & $\begin{array}{r}5.4 \\
(8 \text { 位) }\end{array}$ & $\begin{array}{r}6.0 \\
(8 \text { 位) }\end{array}$ & $\begin{array}{r}2.7 \\
(15 \text { 位 })\end{array}$ & $\begin{array}{r}4.3 \\
(14 \text { 位) }\end{array}$ & $\begin{array}{r}3.4 \\
(16 \text { 位) }\end{array}$ & $\begin{array}{r}2.8 \\
(17 \text { 位) }\end{array}$ \\
\hline
\end{tabular}

出典：(1)は長崎県観光統計, (2)は JNTO 日本の国際観光統計 2010 年 (平成 22 年), (4)はJNTO 訪日外客訪問地調査 2010 による。 (2)は商用客，その他客，一時上陸客を含まない。なお，2013 年の(2)は日本政府観光局ホームページ, (4)は観光庁「訪日外 国人の消費動向 訪日外国人消費動向調査結果及び分析 平成 25 年 年次報告書」（ホームページ版）による。（いずれ も2014 年 6 月 2 日にアクセス

表２＼cjkstart長崎県および主要地区における外国人宿泊客数

\begin{tabular}{lrrrrrc}
\hline & 1994 年 & 1997 年 & 2002 年 & 2007 年 & 2010 年 & 2013 年 \\
\hline 長崎県における外国人宿泊客数 (単位:人。以下同様) & 64,966 & 215,159 & 197,161 & 397,553 & 319,445 & 380,854 \\
うち長崎市とその周辺 & 19,990 & 58,292 & 48,706 & 63,197 & 110,150 & 134,522 \\
佐世保市とその周辺 & 35,618 & 139,768 & 121,154 & 246,924 & 141,862 & 127,611 \\
島原半島 & 6,386 & 11,533 & 15,705 & 26,698 & 17,290 & 16,903 \\
対馬 & 959 & 1,226 & 8,402 & 45,479 & 40,154 & 89,981 \\
その他 & 2,013 & 4,340 & 3,194 & 15,255 & 9,989 & 11,837 \\
\hline
\end{tabular}

出典：長崎県統計による。なお,「長崎市とその周辺」は「長崎・西彼」「佐世保市とその周辺」は「佐世保・再開・東彼・北松」 という原表記を改めたものである。

表 3 長崎県に扔ける韓国人宿泊客数抄よび全国における韓国人観光客数の推移

\begin{tabular}{crrrrrr}
\hline & 1994 年 & 1997 年 & 2002 年 & 2007 年 & 2010 年 & 2013 年 \\
\hline (1)長崎県における韓国人宿泊客数 (人) & 8,369 & 22,975 & 77,105 & 236,670 & 176,380 & 174,469 \\
うち長崎市とその周辺 & 4,015 & 10,327 & 19,986 & 31,946 & 47,278 & 45,601 \\
佐世保市とその周辺 & 1,035 & 3,275 & 36,397 & 131,942 & 72,622 & 22,770 \\
$\quad$ 対馬 & 866 & 1,171 & 8,370 & 45,433 & 40,106 & 89,912 \\
(2) 全国に㧍ける韓国人観光客数 (人) & 511,753 & 587,299 & 756,991 & $2,084,195$ & $1,963,002$ & $1,974,117$ \\
(3) (1) (2) (\%) & 1.52 & 3.91 & 10.19 & 11.36 & 8.99 & 8.84 \\
\hline
\end{tabular}

出典：(1)は長崎県観光統計，(2)は JNTO 日本の国際観光統計 2010 年（平成 22 年）による。なお，2013 年の(2)については，日 本政府観光局ホームページによる(2014 年 6 月 2 日アクセス)。以下表 5 , 表 6 , 表 7 についても同様である。

表 4 韓国抢よび台湾の団体ツアーによる九州北部の主要観光地の訪問率

\begin{tabular}{|c|c|c|c|c|c|}
\hline 訪問率 & \multicolumn{3}{|c|}{ 韓国の団体ッアー } & \multicolumn{2}{|c|}{ 台湾の団体ッアー } \\
\hline $70 \%$ 以上 & 福岡市 太宰府天満宮 & 別府 湯布院 & 阿蘇山 & 福岡市 太宰府天満宮 & ハウステンボス \\
\hline $50 \%$ 以上 $70 \%$ 未満 & 熊本市 & & & 湯布院＼cjkstart柳川 & \\
\hline $30 \%$ 以上 50 \%未満 & & & & 長崎市 阿蘇山 別府 & 天山スキー場 \\
\hline
\end{tabular}

出典：韓国および台湾の大手旅行社 4 社のホームページに掲載された, 2010 年 1 月中旬から 2 月末の間に出発する団体ツアーを 考察の対象とした。

表 5 長崎県における台湾人宿泊客数および全国における台湾人観光客数の推移

\begin{tabular}{crrrrrr}
\hline & 1994 年 & 1997 年 & 2002 年 & 2007 年 & 2010 年 & 2013 年 \\
\hline (1)長崎県における台湾人宿泊客数 (人) & 34,949 & 135,683 & 55,317 & 95,401 & 64,309 & 100,889 \\
うち長崎市とその周辺 & 4,121 & 25,202 & 4,721 & 9,317 & 12,552 & 21,222 \\
佐世保市とその周辺 & 26,807 & 105,188 & 49,053 & 79,711 & 47,301 & 74,102 \\
(2) 全国における台湾人観光客 (人) & 562,053 & 725,785 & 769,074 & $1,255,642$ & $1,139,339$ & $2,067,269$ \\
(3) (1) (2) (\%) & 6.22 & 18.69 & 7.19 & 7.60 & 5.64 & 4.88 \\
\hline
\end{tabular}


表 6 は長崎県における中国人宿泊客数，全国におけ る中国人観光客数および前者の後者に対する割合を示 したものである。たしかに中国人の宿泊客数自体は近 年増加傾向にある。しかし長崎県における中国人の宿 泊客数の，わが国を訪問する全中国人観光客に占める 割合は逆に大きく低下している。これはわが国を訪問 する中国人観光客が特に 2000 年代以降急増したもの の, その多くが, 東京, 大阪, 京都, 山梨などの都道 府県を含めたいわゆるゴールデンルートに集中してい るためと考えられる（JNTO，2011b）。一方, 長崎県 については, 中国人観光客が日本観光において最も重 要な項目の 1 つと考えているショッピングの目的地と しての大都市がなく，観光地としての魅力が東京都や 大阪府などに比べてはるかに小さいと考えられる。さ らに中国と日本の間では 2012 年以降，尖閣列島をめ ぐる領土問題が深刻化していることも，国際観光に大 きな影響を与えていると考えられる ${ }^{16)}$

表 7 は長崎県におけるヨーロッパ人宿泊客数, 全国 におけるヨーロッパ人観光客数および前者の後者に対 する割合を示したものである。なおここではヨーロッ パのうち，イギリスからの宿泊客を除いた数值を示し た ${ }^{17)}$ 。県内における分布では長崎市とその周辺への 集中率が圧倒的に多い。これは特にハウステンボスの 人気が台湾などのアジアからの宿泊客に比べてかなり 低いためと考えられる。次に宿泊客数については比較 的順調に増加しているが, 長崎県におけるヨーロッパ 人宿泊客数の全国におけるヨーロッパ人観光客数に 占める割合は伸び悩んだままであり，特に 2007 年に は減少幅が大きい。この理由としては 2007 年に世界 的に最も高い評価を受けているガイドブックの 1 つで あるフランスのミシュランの日本版が発行され，ヨー ロッパにおける日本への注目度は高まったものの，長 崎県の観光地の評価はあまり高くないためと考えられ る。同ガイドは日本の主な観光地を一つ星, 二つ星,
三ツ星の 3 段階に区分して評価を行っているが，特に 三ツ星評価を受けた観光地についてはその大半が関 東地方や関西地方, 中部地方などに集中しており ${ }^{18)}$, 長崎県を含めた九州地方の観光地の評価はあまり高い とは言えない ${ }^{19)}$ 。

たしかに同ガイドでは長崎市が二つ星観光地に指定 され，九州の主要都市の中では最も評価が高い。また 同市には東山手地区や南山手地区のような伝統的建造 物保存地区に指定された地区が存在する ${ }^{20)}$ 。にもかか わらず, 同ガイドにおける長崎市の評価は, 同じ伝統 的建造物保存地区が存在する高山や金沢などに比べて 低い。その背景としては長崎市における伝統的建造物 の多くが大浦天主堂やグラバー邸に象徴される洋風建 築であり，京都や奈良，さらには高山や金沢のように 日本情緒の象徵的存在ともいえる和風建築の比率が高 い都市の建造物に比べて評価が低いことが考えられる。

以上に述べたように，長崎県はわが国を訪問する外 国人観光客が本格的に増加する前の 1990 年代までは 外国人観光客の訪問率でかなり上位を占めていた。特 に2001 年まで長崎県における宿泊客数が最も多かっ た台湾からの観光客については，表 5 にあるように最 盛期にはわが国を訪問する台湾人観光客の 5 分の 1 近 くが長崎県, 特にハウステンボスのある佐世保市とそ の周辺に宿泊していた。

しかし 2000 年代に入ると, 確かに長崎県における 外国人の宿泊客数それ自体は増加し，特に 2007 年に は 236,670 人と過去最高を記録したものの, 長崎県へ の訪日外客訪問率，あるいは同県における外国人宿泊 客数のわが国を訪問した観光客総数に占める割合など から見た場合, 国際観光における長崎県の地位は相対 的に低下していると言える。

このような状況に至ったのは，これまで見てきたよ うに, 特に 2000 年代以降, 長崎県において安定して 増加を続けている国籍の外国人観光客が存在しない

表 6 長崎県における中国人宿泊客数㧍よび全国における中国人観光客数の推移

\begin{tabular}{|c|c|c|c|c|c|c|}
\hline & 1994 年 & 1997 年 & 2002 年 & 2007 年 & 2010 年 & 2013 年 \\
\hline (1)長崎県における中国人宿泊客数（人） & 1,348 & 3,471 & 6,121 & 12,224 & 15,384 & 16,608 \\
\hline うち長崎市とその周辺 & 688 & 2,968 & 2,298 & 3,045 & 6,924 & 12,419 \\
\hline 佐世保市とその周辺 & 376 & 237 & 2,392 & 6,418 & 6,320 & 1,975 \\
\hline (2)全国における中国人観光客（人） & 24,550 & 33,431 & 101,299 & 407,288 & 831,652 & 704,737 \\
\hline (3) (1) $\div$ (2) $(\%)$ & 5.49 & 10.38 & 6.04 & 3.00 & 1.85 & 2.28 \\
\hline
\end{tabular}

表 7 長崎県におけるヨーロッパ人宿泊客数および全国におけるヨーロッパ人観光客数の推移（いずれもイギリスを除く）

\begin{tabular}{|c|c|c|c|c|c|}
\hline & 1997 年 & 2002 年 & 2007 年 & 2010 年 & 2013 年 \\
\hline $\begin{array}{l}\text { (1)長崎県に扔けるヨーロッパ人（イギリスを除く） } \\
\text { 宿泊客数（人） }\end{array}$ & 2,722 & 5,638 & 5,772 & 9,136 & 16,016 \\
\hline うち長崎市とその周辺 & データなし & 5,010 & 4,701 & 8,424 & 14,993 \\
\hline 佐世保市とその周辺 & データなし & 347 & 528 & 269 & 524 \\
\hline $\begin{array}{l}\text { (2)全国におけるヨーロッパ人（イギリスを除く） } \\
\text { 観光客数（人） }\end{array}$ & 148,650 & 197,052 & 356,575 & 418,922 & 446,653 \\
\hline (3) (1) $\div$ (2) $(\%)$ & 1.83 & 2.86 & 1.62 & 2.18 & 3.59 \\
\hline
\end{tabular}


ことが挙げられる。そしてその背景としては，特に 2000 年代以降の台湾人観光客の減少，あるいは 2007 年のミシュランガイドの日本版の発行を契機とする, ヨーロッパからの観光客の金沢, 高山などの中部地方 への訪問数の急増に象徵されるような，長崎県の観光 地に対する外国人観光客の評価の低迷が挙げられる。 たしかに長崎県にはヨーロッパ諸国や中国などのアジ ア諸国との交流の中で培われた異国情緒が存在し，そ のことは少なくとも日本人観光客からは一定の評価を 受けている。また比較的温暖な気候条件も見逃せない。

しかしこれらの観光資源は，外国人観光客の側から は必ずしも魅力のあるものとしては捉えられていな い。長崎県では台湾人観光客の好むような雪景色はほ とんど見ることができず，ヨーロッパ人観光客の好む ような日本情緒を満喫できるような場所でもなく，ま た中国人観光客が好むようなショッピングを楽しめる 大都市も存在しない。そして，日本人観光客を引き付 けている異国情緒や温暖な気候は, 外国人観光客には むしろマイナスの影響を与えているとさえ言うことが できる。

ただしこのことは，見方を変えれば，日本が国際観 光の目的地として, 外国人観光客の間では地方ごとの 特徴に至るまでかなり広く知られるようになっている ことを示しているとも考えられる。

\section{III. 長崎県の国際観光再興に向けた展望}

本章では前章に示した状況を踏まえた上で，長崎県 が今後, 国際観光の活力を取り戻すためにはいかなる 対策が必要なのか, 特に政治的要因や経済的要因に比 べてより長期的な視点に基づいた対策を必要とする, 外国人観光客の嗜好, 特に彼らの観光地としての長崎 県に対する評価の向上に重点を置いて検討する。ここ ではまず, このような状況を打開するためには, 団体 旅行者と個人旅行者のどちらにより重点を置くべき か，また，実際に長崎県を訪問した外国人観光客が観 光地としての長崎県をいかに評価しているのかアン

表 8 日本の主要観光地における団体旅行者の比率

\begin{tabular}{l|ll}
\hline 全観光地の平均 & & 38.2 \\
\hline 日本の主要都市 & 東京 23 区 & 20.5 \\
& 京都市 & 35.7 \\
& 大阪市 & 38.4 \\
\hline 長崎県の観光地 & 長崎市 & 38.9 \\
& 雲仙温泉 & 69.2 \\
& ハウステンボス & 59.8 \\
& 佐世保市 & 52.9 \\
\hline \multirow{2}{*}{ その他の地方都市 } & 札幌市 & 55.6 \\
& 福岡市 & 35.4 \\
& 別府市 & 67.6 \\
& 広島市 & 12.8 \\
\hline
\end{tabular}

単位：\%。

出典：JNTO 訪日外客訪問地調査 2010 による。
ケートの結果をもとに確認することにする。

表 8 は, 日本の主要観光地における団体旅行者の比 率を示したものである。これによると，長崎県の観光 地は東京や大阪などから遠いこともあり，長崎市を除 いて団体旅行者の比率がかなり高い。しかし前章で述 ベたように，長崎県の観光地は，表に示した札幌市の ある北海道の観光地に比べて人気が低く，団体観光客 だけでは集客力の大きな増加は期待できない。ゆえに このように団体旅行客への依存率が高い状態から脱却 することが, 国際観光の停滞から脱却するための $1 つ$ の重要な手段であると考えられる。

また表 9 は，長崎市を訪問した外国人観光客の訪問 理由を示したものである。これによると，確かに長崎 市は表 8 で示したように, 県内の観光地の中では例外 的に個人旅行者の比率が高いものの, 訪問理由の中で は特に「行きたい観光地があるから」や「長崎」とい うイメージに魅かれたという回答の比率が低く, 長崎 市は外国人観光客にとっては必ずしも積極的に訪問し たい都市ではないと考えられる。

表 10 は，長崎市における主要観光地の入場者数ま たは訪問率を示したものである。ここでは外国人観光 客の訪問先が平和公園や原爆資料館に集中する傾向が 強く, 逆に長崎市の中心に位置し, 原爆とは直接関係 のないグラバー園などの観光地の訪問率が日本人観光 客に比べて極めて低いことがわかる。さらに表 11 は 外国人観光客が長崎市の観光地としての課題として挙 げた項目を示したものであるが，ここでは特に市内宿 泊の外国人観光客が, 観光地の整備や観光情報の提供 が不十分であると考えている比率が高いことが注目さ れる。

以上のことから, 今後, 長崎県の国際観光地として の評価をより高めていくためには，外国人観光客，特 に個人観光客の満足度をより高めていくことが何より も重要であると考えられる。

次にその具体的な方法としては，大きく 2 つの点が 挙げられる。1つは, 外国人観光客が長崎県の観光地

表 9 外国人観光客が長崎市を訪問した理由

\begin{tabular}{|c|c|c|}
\hline 順位 & 理由 & 割合（\%） \\
\hline 1 位 & ッアーの訪問地に入っていたから & 38.0 \\
\hline 2 位 & 長崎の歴史や文化に興味があるから & 17.8 \\
\hline 3 位 & 被爆地だから & 13.9 \\
\hline 4 位 & 行きたい観光地があるから & 12.5 \\
\hline 5 位 & 「長崎」というイメージに魅かれて & 5.3 \\
\hline $\begin{array}{l}\text { 単位 } \\
\text { 出典 }\end{array}$ & \multicolumn{2}{|c|}{ 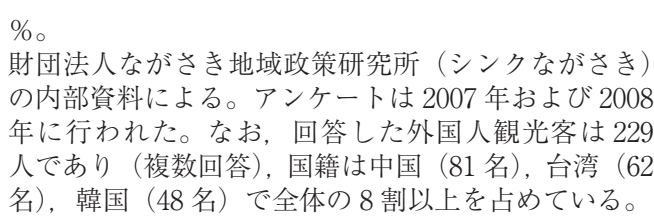 } \\
\hline
\end{tabular}


表 10 長崎市における主要観光地の入場者数または訪問率

\begin{tabular}{|c|c|c|c|c|}
\hline 調査内容 & $\begin{array}{l}\text { (1)主要観光地の } \\
\text { 入場者数 (人) }\end{array}$ & $\begin{array}{l}\text { (2) 国内観光船利用客の } \\
\text { 観光地訪問率 (\%) }\end{array}$ & $\begin{array}{c}\text { (3)国際観光船利用客の } \\
\text { 観光地訪問率 }(\%)\end{array}$ & $\begin{array}{l}\text { (4)市内宿泊の } \\
\text { 外国人観光客の } \\
\text { 観光地訪問率 }(\%)\end{array}$ \\
\hline $\begin{array}{l}\text { 入場者数または } \\
\text { 訪問率 } 1 \text { 位の観光地 }\end{array}$ & $\begin{array}{l}\text { グラバー園 } \\
882,820\end{array}$ & $\begin{array}{c}\text { グラバー園 } \\
63.6\end{array}$ & $\begin{array}{c}\text { 平和公園 - 原爆資料館 } \\
75.8\end{array}$ & $\begin{array}{c}\text { 平和公園 - 原爆資料館 } \\
42.9\end{array}$ \\
\hline $\begin{array}{l}\text { 入場者数または } \\
\text { 訪問率 } 2 \text { 位の観光地 }\end{array}$ & $\begin{array}{c}\text { 長崎原爆資料館 } \\
663,277\end{array}$ & $\begin{array}{l}\text { 出島 } \\
46.5\end{array}$ & $\begin{array}{c}\text { グラバー園 } \\
41.8\end{array}$ & $\begin{array}{l}\text { 稲佐山 } \\
20.8\end{array}$ \\
\hline $\begin{array}{l}\text { 入場者数または } \\
\text { 訪問率 } 3 \text { 位の観光地 }\end{array}$ & $\begin{array}{c}\text { 長崎歴史文化博物館 } \\
519,407\end{array}$ & $\begin{array}{c}\text { 中華街 } \\
39.5\end{array}$ & $\begin{array}{l}\text { 出島 } \\
26.2\end{array}$ & $\begin{array}{c}\text { 長崎歴史文化博物館 } \\
18.7\end{array}$ \\
\hline $\begin{array}{l}\text { 入場者数または } \\
\text { 訪問率 } 4 \text { 位の観光地 }\end{array}$ & $\begin{array}{c}\text { 長崎県美術館 } \\
392,544\end{array}$ & $\begin{array}{c}\text { 平和公園 · 原爆資料館 } \\
25.6\end{array}$ & $\begin{array}{c}\text { 中華街 } \\
23.7\end{array}$ & $\begin{array}{c}\text { 出島 } \\
7.0\end{array}$ \\
\hline $\begin{array}{l}\text { 入場者数または } \\
\text { 訪問率 } 5 \text { 位の観光地 }\end{array}$ & $\begin{array}{c}\text { 出島 } \\
375,586\end{array}$ & $\begin{array}{c}\text { 浜町アーケード } \\
17.1\end{array}$ & $\begin{array}{c}\text { 浜町アーケード } \\
11.1\end{array}$ & $\begin{array}{c}\text { グラバー園 } \\
3.6\end{array}$ \\
\hline
\end{tabular}

出典：(1)は長崎県観光統計（2009 年), (2)〜 (4)は財団法人ながさき地域政策研究所（シンクながさき）の内部資料 (2)は 2007 年, (3)は 2006 年, (4)は 2007 年および 2008 年にアンケートを実施) による。また(2)の回答者数は 129 人, (3)の回答者数は 413 人（うち中国 114 人，イギリス 84 人，アメリカ 68 人，カナダ 58 人の合計で 8 割弱を占める), (4)の回答者数は 229 人（表 9 と同じ）である。

表 11 外国人観光客からみた長崎市の観光地としての課題

\begin{tabular}{clrll}
\hline $\begin{array}{c}\text { 外国人観光客が改善が } \\
\text { 必要だと考えた項目 }\end{array}$ & \multicolumn{2}{c}{ (1)国際観光船利用客 } & & \multicolumn{2}{c}{ (2)市内宿泊の外国人観光客 } & \\
\hline 1 位 & お土産になるものが少ない & 14.8 & まつりやイベントの充実 & 15.3 \\
2 位 & 観光施設が少ない & 14.3 & 史跡・名所などをもっと整備する & 12.1 \\
3 位 & 標識・案内板がわかりにくい & 7.3 & 情報提供サービスの充実 & 11.4 \\
4 位 & 日本らしさが感じられない & 5.3 & クレジットカートが利用できる施設の充実 & 10.1 \\
\hline
\end{tabular}

単位:\%。

出典 : 財団法人ながさき地域政策研究所（シンクながさき）の内部資料 (11は 2007 年, (2)は 2008 年にアンケートを実施)による。 なお(1)は表 10 の(3),(2)は同じく表10の(4)と同じ母集団である。

としての魅力をより高く評価できるような観光のあり 方とはいかなるものか検討し，それを外国人観光客に 積極的に提示することである。もう1つは長崎県の観 光地としての魅力はいかなるものなのか客観的に評価 し，その上でそれをより高く評価している外国人観光 客の属性はいかなるものか正確に把握することである。

このうち前者の例としては，現在は主に日本人観光 客を対象としているものの, 2006 年以降現在まで続 いている「さるく」を参考にすることができる。「さ るく」とは,「まちをぶらぶら歩くという意味の長崎弁」 である（長崎さるくの公式ホームページによる。2014 年 2 月 17 日アクセス。）長崎市はわが国がバブル経済 の絶頂期にあった 1990 年に, 多くの企業をスポンサー とする「旅博覧会」を開催し，同年に長崎市とその 周辺では国内観光客を中心に $1,710,413$ 人が宿泊した。 しかしその後はバブル経済の崩壊もあって, 同市への 宿泊客数は減少し, 1998 年以降は 100 万人を割り込み, 2000 年代前半には 60 万人台にまで落ち込んた（各年 度の長崎県観光統計のホームページによる。2013 年 12 月 7 日アクセス)。

このような状況を打開するために考案されたものが 「さるく」博覧会である。これは 2006 年に長崎市役所
が中心となって設定したもので，様々なテーマに沿っ た観光地を散策するコースを設定し（図 1)，参加者 に自らの好むコースを選んで参加してもらうという画 期的な試みであった。これらのコースはその多くが所 要時間 2 時間前後, 歩行距離 $2 \mathrm{~km}$ 前後の短いものであ り，いずれも特定の項目に絞った明確なテーマが設け られている。またコースを自由に散策することも可能 であるが，事前予約によるガイド付きのコースも設け られている。なおガイド付きの場合, 参加人数は 1 コー ス当たり 15 人前後に制限されている ${ }^{21)}$ 。

このようなコース設定からも明らかなように，「さ るく」は団体観光客よりも個人観光客を重視し，また 観光バスなどを利用して有名な観光地のみを訪問する のではなく，特定のテーマに関する限られた数の観光 地を観光客が自由に，あるいはガイドとともに小さな 路地に至るまで時間をかけて歩くことに重点を置いた ものである。その背景にはバブル崩壊以降, 日本の観 光が団体客中心から個人客中心に変化したことを考慮 し，また長崎市のもつ様々な歴史的観光資源を観光客 により時間をかけて味わってもらうことを重視しよう とする姿勢があった。この「さるく」博覧会は長崎市 の魅力をより深く味わえるという点が評価され，予想 


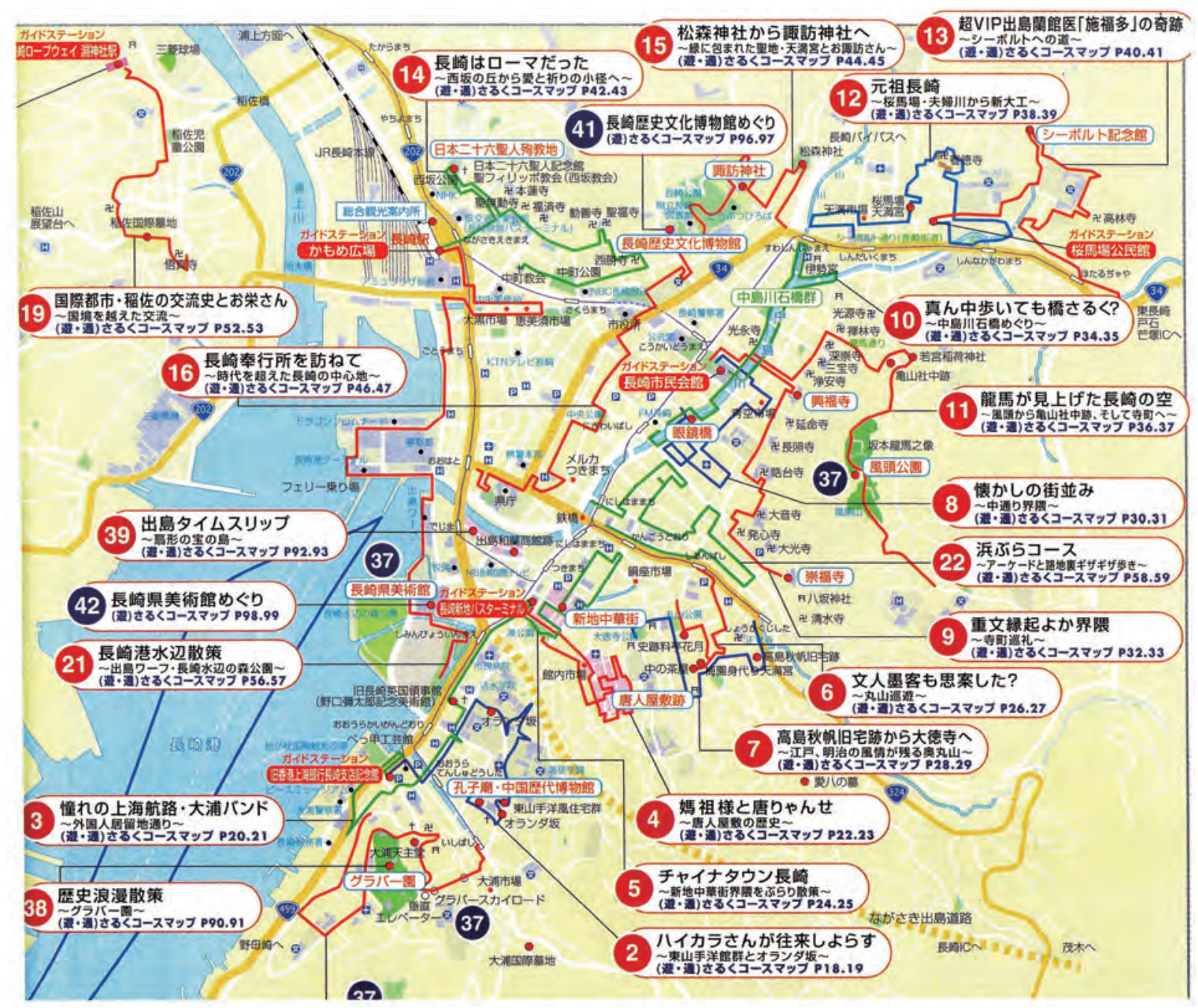

図 1 長崎市中心部における「さるく」ルートの分布（2006 年）

長崎市役所の内部資料による。なお，一部のルートまたはルートの名称について，現在（2014 年）と異なるものが存在する。

以上の人気を博したことから，翌 2007 年以降も名称 を「さるく」と変更した上で継続することが決定され， 現在に至っている。

表 12 は各年に打けるさるくの参加人数を示したも のである。ここにあるように翌年の 2007 年には参加 人数は前年の半分以下に減少したものの 2009 年から は回復し, NHK 大河ドラマ「龍馬伝」が開催された 2010 年には, 長崎市と縁の深い坂本龍馬の足跡を求 めて多くの観光客が訪問したこともあって, 参加人数 は2006 年とほぼ同一の水準に達した。翌 2011 年には 再び減少したものの, その後は参加人数がほぼ 3 万 5 千人から 4 万人程度で定着している ${ }^{22)}$ 。

なお，2011年からは中国，2012 年からは韓国か
らの観光客を対象とした「さるく」も開始されてい る ${ }^{23)}$ 。たしかに今後の動向については未知数の部分 が多いものの，前述のように「さるく」が主に団体観 光客よりも個人観光客を対象として創設されたもので あること，同じく前述のように今後，長崎県の国際観 光の復活のためには外国人の個人観光客が重要なキー ポイントとなることを考慮すると，その動向には，長 崎県の今後の国際観光について考える上で参考になる 部分が多いと考えられる。またこの「さるく」は長崎 市のみならず，特に中心市街地に歴史的な史跡が集中 している島原，平戸などの県内の他の観光都市にも応 用することが可能であると考えられる。

次に後者については長崎県, 特に長崎市がこれまで

表 12 長崎さるくの参加者数の推移（2006 年から 2013 年まで）

\begin{tabular}{crrrrrrrr}
\hline & 2006 年 & 2007 年 & 2008 年 & 2009 年 & 2010 年 & 2011 年 & 2012 年 & 2013 年 \\
\hline さるくの参加人数 & 52,398 & 22,937 & 22,620 & 39,536 & 51,209 & 26,847 & 36,897 & 40,000 \\
うち通さるく参加人数 & 48,973 & 20,322 & 18,615 & 33,262 & 38,173 & 18,253 & 21,407 & 22,400 \\
学さるくおよび食さるく参加人数 & 3,425 & 2,615 & 4,005 & 6,274 & 13,086 & 8,594 & 15,490 & 17,600 \\
\hline
\end{tabular}

出典：長崎国際観光コンベンション協会の内部資料による。 
ポルトガル, オランダ, 中国, イギリス, フランス, ポー ランドなどの数多くの国々と交流を行い, 狭い範囲に 様々な文化が共存し，また新たな文化を育んできたこ とを外国人観光客により積極的に伝えていくことが重 要であると考えられる。たしかに長崎県は被爆地とし て, 外国人観光客に平和や戦争放棄などの大切さを伝 える重要な場所としては少なからず認識されているも のの, 様々な文化の共存やそれらが新たな文化を生み 出してきたこと, あるいは交流を通じての国際交流精 神をも学ぶことのできる場所としての価值は, 前述の ように原爆関係以外の観光地の知名度が非常に低いた め，まだ十分に知られているとは言えない。

次にこのために長崎県を訪問する外国人観光客に特 にアピールする価值がある観光要素としてはまず，中 国との文化交流の伝統が挙げられる。長崎には中華街, 孔子廟, 崇福寺などの中国との文化的交流を示す史跡 が多く，また「おくんち」や長崎ランタンフェスティ バルのような祭礼やちゃんぽんなどの食品にも中国の 影響が見られるものが多い。たしかにI章で指摘した ように, 長崎県を訪問する外国人観光客の中で, 台湾 や中国などからの宿泊客数は近年伸び悩みが大きい。 また彼らの多くはショッピングへの関心が高く, 歴史 や文化への関心の高い観光客の割合は必ずしも多いと は言えない。しかしこれらの中国系の観光客は, 台湾 からの観光客だけでも長崎県を訪問する外国人観光客 の中では韓国人観光客に次いで多いこと，また彼らの 言語や文化は韓国からの観光客と同様に日本の言語や 文化との類似性が高く, ゆえに他国籍の外国人観光客 に比べて長崎の文化や歴史をより深く理解することが 容易であることを考えるとその存在意義は決して無視 できないと考えられる。

もう一つの重要な要素としては，隠れキリシタンの 伝統が挙げられる。長崎県には江戸時代に禁教令など による厳しい弾圧を受けたにも関わらず，明治時代に 信教の自由が許されるまで 250 年以上もキリスト教の 信仰を守り通した隠れキリシタンによって建てられ， 現在も礼拝が行われているや教会が県内のあちこちに 分布しており，これは世界でも稀有な存在と言える ${ }^{24)}$ 。

これらの長崎県内一円に分布するカトリック教会 (図 2) は2007 年にわが国において,「長崎の教会群 とキリスト教関連遺産」として, 世界文化遺産登録の ための暫定リストに登録されている（毎日新聞, 2007 年 1 月 24 日)。これらの教会群が将来, 世界遺産とし て国際的に広く認知されるようになった場合, 例えば フランス, イタリア, スペイン, ポルトガル, ポーラ ンドといった, カトリック教徒が国民の大多数を占め, かつ長崎との関係も深いヨーロッパの国々, あるいは 前述のように長崎県における宿泊客数が最も多く, ま たキリスト教徒が国民のほぼ半数を占める韓国からの

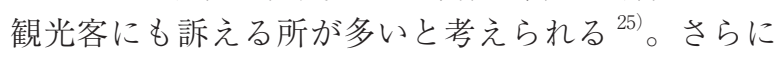
2014 年にローマ法王庁が「長崎の教会群とキリスト 教関連遺産」の世界遺産への登録を支援する意向を表 明した（朝日新聞， 2014 年 3 月 5 日）ことは, 外国

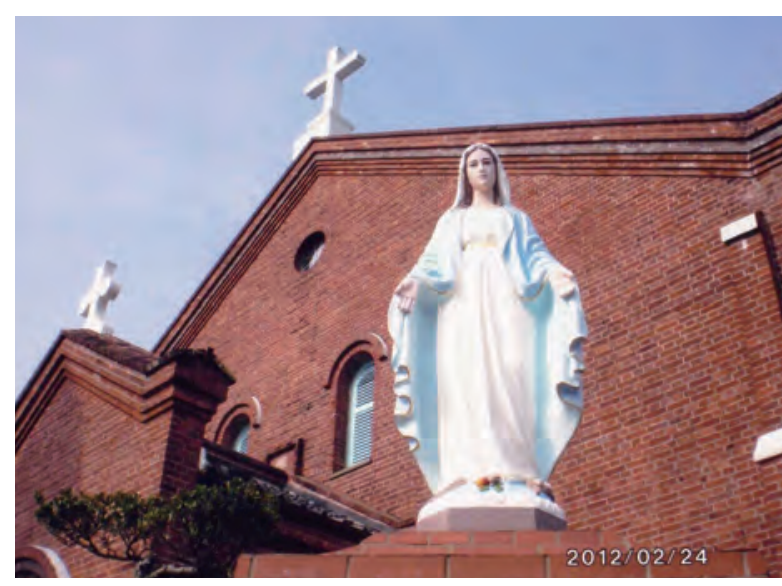

図 2 黑崎天主堂

長崎市外縁部の外海地区にあり, 2007 年に大浦天主堂や浦上 天主堂などとともに「長崎の教会群」としてわが国の世界遺産 候補に指定された。

人観光客に観光地としての長崎県の価值や知名度を高 める上で大きな影響を与えたことは否定できず，今後 の動向が注目される。

\section{IV . おわりに}

本研究においては近年, 国際観光が停滞傾向にある 県の1つである長崎県を取り上げ，その停滞の要因に ついて様々な国籍の外国人宿泊客の増減およびその背 景について長期的に検討し，また国際観光の今後の復 活に向けて留意すべき点についても考察を加えた。

その結果, 長崎県の国際観光の停滞については, 冬 の雪景色, ショッピングを行うための大都市, 日本独 自の文化的伝統を象徴するような寺社や集落といっ た，外国人観光客に人気のある要素に乏しいこと，ま た，その割には団体ツアーへの依存度が高く，かつ原 爆関係を除くと外国人観光客における観光地の知名度 がかなり低いことが特に大きな理由であることが明ら かになった。

このような状況を打開するためにはまず，外国人観 光客の間で観光地としての長崎県の魅力を高める上で 最も望ましい観光スタイルを提示することが重要であ ると言える。その中でも特に，2006年に長崎市にお いて開始された「さるく」は, 現在は主に日本人観光 客を対象としているものの, 観光バスなどで有名な観 光地のみを選んで見るのではなく, 特定のテーマに 沿った限られた数の観光地を個人で，あるいはガイド とともに十分に時間をかけて歩くコースを多数設定し ており，観光の重点をそれまでの団体観光客から個人 観光客に移したことで, 今後, 長崎県の観光地をより 高く評価する外国人観光客, 特に個人観光客を新たに 呼び达む契機となる可能性を有していると言える。

次に重要なことは, 長崎県の観光地あるいは観光要 素の文化的価值，特に様々な外国文化が共存し，また それらの融合により新たな文化が生み出されてきたと いう事実を多くの外国人により積極的に紹介し，かつ それを高く評価する可能性の高い外国人観光客の属性 
をより正確に把握するための努力を続けることであ る。特に中国との文化交流を示す観光地や食品, ある いは隠れキリシタンの伝統を持つ教会群は外国人観光 客の間でもすでにある一定の評価を受けるようになっ ており，このことが新たな外国人観光客，特に個人観 光客の流れを産み, 長崎県が国際観光の主要目的地と して再びその地位を高めるようになる可能性は十分に あると言える。特に長崎県と同様にカトリックの伝導 が行われ，地元のインデイオと新たな来訪者である白 人や黒人の文化との融合により新たな文化が形成され てきたことを示すラテンアメリカの史跡の中で，す

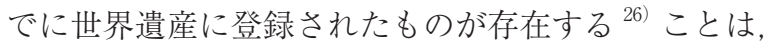
長崎県の国際観光地としての新たな飛躍の可能性を示 唆するものと言える。

最後に, 本研究で扱ったような国際観光への地理学 からのアピールのあり方についても言及したい。これ までわが国において，国際観光については経済学，経 営学をはじめ, 様々な学問分野からのアピールが行わ れてきたが，その多くが主に地元の経済的利益に重点 を置いてきたものであることは否定できない。しかし 今後, 国際観光研究における地理学のオリジナリティ をより確固たるものにするためには，ただ地元の経済 的利益や，国際観光に関わる様々な主体の関係の分析 のみに終始するのではなく，伝統的に空間と時間の多 様性に基礎を置いてきた学問として，地方ごとの観光 資源の多様性，同じ観光地に対する外国人観光客の評 価の多様性, さらに海外旅行のあり方の変化などの指 標を通して，観光地および外国人観光客双方の多様性 を何よりも尊重し，それに基づいてより望ましい形の 観光のあり方を積極的に提示していくことがより重要 になるのではないかと考えられる。

さらに今後の研究課題としては, 日本各地の観光地 に対する海外からの評価およびその経年的変化につい てよりフィールドを広げて研究を進めること，また海 外における日本人観光客の観光行動の経年的変化やそ の背景について検討を進めることなどが挙げられる。

\section{謝辞}

本稿の執筆にあたり貴重なご意見をいただいた，中 部大学名誉教授の中藤康俊先生, 立教大学の杜 国慶 先生, 近畿大学の辰已勝先生, お忙しい中, 貴重な内 部資料を快く公開して下さった財団法人ながさき地域 政策研究所（シンクながさき）の原田幸二様, 長崎国 際観光コンベンション協会の本庄寛伸様, 長崎市役所 の大久保俊哉様，さらに本稿の作成にあたり討論の機 会を与えて下さった，わが国および海外各国の地理学 関係者の皆様に厚く御礼申し上げます。なお本研究の 内容については，2012 年 10 月に神戸大学で開催され た日本地理学会秋季学術大会において発表しました。

\section{注}

1）わが国を訪問する外国人観光客数（商用客などは含まない） は東日本大震災発生前の 2010 年には過去最高の 6,361,974 人に達していた（JNTO，2011a）。なお 2013 年には円安や 東南アジアからの観光客の増加などにより，この数值をさ らに上回る7,962,517 人を記録している。JNTOのホーム ページによる (2014 年 6 月 24 日検索)。

2）例として池永 (1999), 加賀美（2002），横山（2007）, 森 本（2009）などがあり, 研究者が自らの研究対象とする国 または地域における国際観光の動向について注目したもの が多い。

3）主なものとして北田（2011）, 小松原（2004）, 清水・祖田 (2005), 清水 (2007), 金 (2009), 吳羽·金 (2009), 松村 (2009) が挙げられる。なお本研究で扱った長崎県における国際観 光を取り上げた研究については 8) を参照。

4） 2013 年現在，わが国を訪問する外国人観光客数を国籍別に みると上から台湾，韓国，香港，中国の順になり（JNTO のホームページによる。2014 年 6 月 24 日検索), 東アジア の国または地域が上位を独占している。

5）北田（2012）は主に富山, 石川, 福井の 3 県と岐阜県の高 山を中心とする飛騨地方の国際観光を取り上げており，両 者を合わせて「北陸および飛騨地方」という呼称を用いて いる。

6）都道府県レベルで 1997 年から 2010 年の間に訪日外客（商 用客なども含む）の訪問率の減少が大きい県としては，本 研究で扱う長崎県の他に沖縄県 $(4.7 \% \rightarrow 2.7 \%$ 。都道府県 別順位では 11 位 $\rightarrow 21$ 位 $)$, 宮崎県 $(2.9 \% \rightarrow 0.3 \%$ 。都道 府県順位では 17 位 $\rightarrow 26$ 位) などがある。数值はいずれも JNTO (2011b) による。

7）九州地方に㧍ける訪日外客の訪問率は 1997 年の $19.0 \%$ か ら 2010 年の $10.9 \%$ \%ときく減少しており, 同じ時期に 2.9 \%から $8.8 \%$ \%と大幅に増加している北海道とは極めて 対照的である。数值はJNTO（2011b）による。

8）長崎県における国際観光を取り上げた既存研究としては, 同県の隠れキリシタンに象徵される伝統的なキリス卜教 文化が観光資源化される過程やその課題に注目した木村 (2007)，松井（2009，2012），ハウステンボスに対する韓 国人大学生のイメージについて調査を行った李 (2002), さらに雲仙温泉を訪問する外国人観光客の客層の変化に注 目した佐藤（2009）などがある。

9）表 1 で数值を示した年はいずれも，世界レベルでの経済不 況やインフルエンザの流行などの国際観光に否定的な影響 を与える要因が少ない年を選んだ。

10） 1990 年代にわが国を訪問した外国人観光客は最多の 1999 年でも $2,560,343$ 人に過ぎず, 2013 年の $7,962,517$ 人の半分 にも及ばなかった。数值はJNTO（2011a）による。

11）表 1 の訪日外客には商用や家族訪問などでわが国を訪問し た外国人も含まれているが，長崎県についてはその大半が 観光客であると考えられる。たしかに米軍基地が存在する 佐世保市とその周辺では親族訪問で宿泊するアメリカ人宿 泊客の存在を無視できないが, 2002 年の 19,262 人をピー クに減少傾向にあり，また，2004 年以降はほぼ毎年，長 崎市とその周辺での宿泊者数が佐世保市とその周辺での宿 
泊者数を上回っていることから（長崎県観光統計のホーム ページによる), その重要性はそれほど大きくないと考え られる。

12）原表においては，長崎市および近辺の市町村を含んだ地区 は「長崎・西彼」，佐世保市抢よび近辺の市町村を含んだ 地区は「佐世保·西海·東彼・北松」と表記されているが, ここでは便宜上，前者を「長崎市とその周辺」，後者を「佐 世保市とその周辺」と表記することにする。また原表には この 2 地区の他に, 表 2 に示した島原半島, 対馬, さらに 平戸・松浦, 諫早·大村, 五島, 壱岐の 4 地区の数值が挙 げられている。

13）ビザの免除は台湾からの短期観光客に対しても実施された。

14）この結果, 2009 年には韓国人観光客が前年の 2008 年と比 べてほぼ半減するに至った（読売新聞，2010 年 7 月 8 日）。

15）台湾から日本への訪日外客については，2002 年に北海道の 訪問率が急上昇し, それ以降ほぼ毎年 $10 \%$ 以上, 全国の 都道府県順位でも8 位を上回っている。これに対して福岡 県や長崎県などの九州諸県の訪問率は徐々に低下し, 全国 順位でも 10 位を下回るようになっている。数值は各年の JNTO 訪日外客訪問地調査（2004 年以前のタイトルは訪日 外国人旅行者調查）による。

16）例えば長崎県では 2011 年 11 月に, 戦前以来の歴史をもつ 上海航路が 14 年ぶりに再開され, 長崎県の観光の活性化 に大きな役割を果たすことが期待されたが，翌 2012 年 10 月には尖閣諸島の領有をめぐり日中関倸が悪化した影響を 受けて運行が休止された(読売新聞, 2012 年 9 月 27 日)。 2013 年には運営会社により同航路の免許の更新も取り下げ られ (読売新聞, 2013 年 2 月 20 日), 再開の目途は立って いない。

17）長崎県に宿泊したヨーロッパからの宿泊客においてイギリ ス人の占める割合は例年 3 割強であるが, 近年, 通貨ポン ドの切り下げや経済情勢の悪化の影響を受けて日本を訪問 するイギリス人観光客数がフランスなどの他のヨーロッパ 諸国と異なり停滞傾向にあることから（JNTO, 2011a）同 列に扱うことが困難であると判断した。

18）特に中部地方には高山や金沢，白川郷などのように，伝統 的な家屋や庭園，工芸品などに恵まれた，いわゆる日本の 古きよき伝統をアピールできる中小都市や集落が多く, こ れらは 2007 年以降, ヨーロッパからの観光客の間で爆発 的な人気を得て訪問客数が急増している（北田，2012）。

19）九州地方については沖縄県・石垣島の川平湾, 鹿児島県の 屋久島, 福岡県の九州国立博物館の 3 か所が三ッ星観光地 に指定されているものの，ヨーロッパ人観光客の評価の高 い, 古い歴史のある都市の旧市街地に立地する観光地の中 で三ツ星評価を受けたものは皆無である（Michelin Cartes et Guides, 2009)。

20）特に南山手地区には大浦天主堂やグラバー園などがあり, 長崎県のみならず，九州を代表する観光地である。

21）以上の経緯については, 長崎国際観光コンベンション協会 のホームページ (http://www.at-nagasakijp/nitca/) に詳 しい（2013 年 10 月 2 日アクセス)。また同じさるくでも各 自が自由に散策するものを「遊さるく」, ガイド付きのコー スを「通さるく」と呼んで区別しており，2014 年現在,「遊
さるく」は 45 コース,「通さるく」は 29 コースある（さる くのホームページ http://www.saruku.info/による。2014 年 2 月 17 日検索)。所要時間については「遊さるく」は「通 さるく」よりも30 分ほど短く想定されている。な扢この 他に, 期間限定で特定のテーマをより掘り下げた「学さる く」や長崎の名物料理を楽しむ「食さるく」もある。

22）表 12 にあるように, 近年は「通さるく」よりも「学さるく」 および「食さるく」の方が参加人数の増加率が大きいこと が注目される。これは「学さるく」や「食さるく」が「通 さるく」よりもさらに専門性が高いこと，また「通さるく」 のかわりに個人単位で「遊さるく」を行う参加者やコース のリピーターが少なくないためと考えられる。

23）中国人観光客向けのさるくには中国文化コース, 異国エリ アコース, 繁華街コース, 平和のコース, 孫文ゆかりの地 コースの 5 コースが, 韓国人観光客向けのさるくには旧外 国人居留地コース, 日本二十六聖人殉教と長崎の歴史コー ス, 平和を学ぶコース, 夕陽が美しいキリシタンの里コー ス〜遠藤周作が魅せられた町, 散策と温泉が楽しめるリ ゾートアイランドの同じく 5 コースがある（さるくのホー ムページによる。2013 年 9 月 5 日検索。）な扢この他に不 定期ではあるが, 案内者が英語で案内を行うコースもある。

24）長崎県あるいは長崎県に抢ける隐れキリシタンの歴史につ いて概観するには，原田（1964），長崎県高等学校教育研究 会社会科部会（1974）, 邦光（1977）などが好適である。な お邦光を除いて近年, 再版または改訂版が市販されている。

25）実際，「長崎の教会群とキリスト教関連遺産」は韓国のカ トリック関係者からも高く評価されている（毎日新聞, 2013 年 4 月 6 日)。なお韓国には長崎県の隠れキリシタン 史跡と同様に, キリス卜教徒の殉教に関連した史跡が各地 に存在する。

26) 例として,「パラナ川北岸のイエズス会伝道所」(パラグア イ。1993 年登録) や「グアラニー族のイエズス会伝道所」 が挙げられる。後者はアルゼンチンとブラジルの国境地帯 に分布し、アルゼンチン領は 1983 年, ブラジル領は 1984 年に世界遺産に指定された。

\section{文献}

朝日新聞（2014）:『世界遺産登録，バチカンが支援 長崎の教会 群とキリスト教関連遺産／長崎県』長崎・1 地方朝刊 2014 年 3 月 5 日, http://database.asahi.com/library2/main/start.php (2014 年 7 月 19 日アクセス).

池永正人（1999）：オーストリアアルプスにおける山岳観光の 発展と山地農民の対応. 人文地理，51（6），62-79.

加賀美雅弘 (2002)：魅惑のアルプスースキーとハイキングで にぎわう国際観光地. 広瀬佳一編著『ウイーン・オーストリ アを知るための 50 章』明石書店, 134-138.

北田晃司 (2011)：沖縄県に扔ける観光の国際化. 地理学論集, $86,24-40$

北田晃司（2012）：日本の国際観光における北陸および飛騨地 方の台頭. 歴史と地理，658，40-49.

木村勝彦（2007）：長崎におけるカトリック教会巡礼とッーリ ズム。長崎国際大学論叢, 7, 123-133.

金玉実 (2009): 日本に抒ける中国人旅行者行動の空間的特徵. 
地理学評論, $82,332-345$.

邦光史郎（1977）：『キリシタンの里』保育社.

吳羽正昭・金 玉実 (2009)：観光行動の空間特性. 神田孝治 編著『観光の空間 - 視点とアプローチ』ナカニシヤ出版, 102-111.

小松原尚 (2004)：観光・リゾート開発．中藤康俊編著『国際 化と地域』原書房，19-36.

佐藤大祐（2009）：観光地の集客圈. 神田孝治編著『観光の空 間－視点とアプローチ』ナカニシヤ出版, 112-122.

清水伊織（2007）：中国人の訪日旅行の形態とその恋化一観光 からッーリズムへー。地理学論集, 82, 37-52.

清水伊織・祖田亮次 (2005) : 北海道におけるアジアからのイ ンバンド・ッーリズム。北海道地理，80，25-39.

JNTO（日本政府観光局）（2011a）:『JNTO 日本の国際観光統 計 2010 年 (平成 22 年)』国際観光サービスセンター.

JNTO (2011b) :『JNTO 訪日外客訪問地調査 2010』国際観光サー ビスセンター。

長崎県高等学校教育研究会社会科部会（1974）：『長崎県の歴史 散歩』山川出版社.

原田伴彦（1964）：『長崎』中公新書.

毎日新聞（2007）:『世界遺産：暫定リストに「長崎の教会群」 など追加一文化庁』西部朝刊 2007 年 1 月 24 日. https://dbs. g-search.or.jp/aps/WMSK/main.jsp?ssid=20130830164542264 gsh-ap01（2013 年 8 月 30 日アクセス）

毎日新聞 (2013)：『ソウル大司教区聖地巡礼団：長崎の教会群, 世界遺産登録へエール/長崎】地方版 / 長崎 2013年4月6日.http:// dbs.g-search.or.jp/aps/WMSK/main.jsp?ssid=20130830164542264 gsh-ap01 (2013 年 8 月 30 日アクセス)

松井圭介 (2009): 聖地創造と消費される文化．神田孝治編著『観 光の空間 - 視点とアプローチ』ナカニシヤ出版, 45-55.

松井圭介（2012）：『観光戦略としての宗教 長崎の教会群と場 所の商品化』筑波大学出版会.

松村嘉久（2009）：大阪国際ゲストハウス地域を創造する試み. 神田孝治編著『観光の空間 - 視点とアプローチ』ナカニシヤ 出版, 264-274.

森本 泉 (2009) : ネパールに抢けるッーリズムの展開とッーリズ ム空間の形成．神田孝治編著『観光の空間－視点とアプローチ』 ナカニシヤ出版, 89-99.

横山 智 (2007): 途上国農村におけるバックパッカー・エンクレー ブの形成ーラオス・ヴァンヴィエン地区を事例としてー。地理 学評論, 80, 591-613.

李 昌訓 (2002)：ハウステンボスの観光イメージ調查分析 - 韓 国の新世代大学生を中心に一。長崎国際大学論叢, 2, 19-25.

読売新聞 (2008)：『観光客, 3 年連続増 外国人伸び率は過去 最高 県の 2007 年統計 $=$ 長崎』西部朝刊 2008 年 6 月 27 日. http://database.yomiuri.co.jp/rekishikan/ (2012 年 2 月 1 日 アクセス) .

読売新聞 $(2010$, 西部朝刊) :『観光客 25 万人増の 2813 万人 県 09 年速報＼cjkstart高速割引など要因』 2010 年 7 月 8 日. http:// database.yomiuri.co.jp/rekishikan/(2012 年 2 月 9 日アクセス). 読売新聞 (2012)：『上海航路運休 早期再開願う声 日中交 流の関係者ショック』西部朝刊 2012 年 9 月 27 日. https:// database.yomiuri.co.jp/rekishikan/yomiuriNewsArticle.
action?yomiuriNewsAr ‥ (2013 年 4 月 27 日アクセス) 読売新聞 (2013)：『上海便の免許 更新取り下げ HTBクルー ズ』西部朝刊 2013 年 2 月 20 日. http://database.yomiuri.co.jp/ rekishikan/yomiuriNewsArticle.action? yomiuriNewsAr... (2013 年 4 月 27 日アクセス)

Michelin Cartes y Guides (2009) : Le guide vert Japon. Michelin Cartes et Guides, Paris, France.

(2014 年 11 月 10 日受理) 